\title{
The effect of anions of transition metal salts on the structure of modified mesostructured silica films and monoliths
}

\author{
A. Faik Demirörs, Mehmet Arslan, Ömer Dag * \\ Laboratory for Advanced Functional Materials, Department of Chemistry, Bilkent University, 06800 Ankara, Turkey
}

Received 1 November 2005; received in revised form 27 August 2006; accepted 5 September 2006

Available online 27 October 2006

\begin{abstract}
The structure of the preformed LC mesophase of water:transition metal salt $\left(\left[\mathrm{M}\left(\mathrm{H}_{2} \mathrm{O}\right)_{6}\right] \mathrm{X}_{2}\right)$ :acid $(\mathrm{HX})$ :oligo(ethylene oxide) (or Pluronics):tetramethylorthosilicate (TMOS) mixture during hydrolysis and partial polymerization of the silica source is maintained upon further polymerization and condensation of the silica species in the solid state. The liquid mixture in early stage of the silica polymerization could be casted or dip coated to a surface of a glass or silicon wafer to produce mesostructured silica monoliths and films, respectively. The silica species and ions (metal ions and anions) influence the structure of the LC mesophases (as a result, the structure of silica) and the hydrophilic and hydrophobic balance in the reaction media. The silica structure can be changed from hexagonal to cubic by increasing, for example, the nitrate salt concentration in the nitrate salt systems. A similar transformation takes place in the presence of very low perchlorate salt concentration. The salt concentration in the mesostructured silica can be increased up to $1.1 / 1.0 \mathrm{salt} / \mathrm{SiO}_{2} \mathrm{w} / \mathrm{w}$ ratio, in mesostructured silica materials by maintaining its lamella structure in $\mathrm{P} 123$ and cubic in the $\mathrm{C}_{n} \mathrm{EO}_{m}$ systems. However, the materials obtained from the P123 systems undergo transformation from lamella to 2D hexagonal upon calcinations. The method developed in this work can be used to modify the internal surface of the pores with various transition metal ions and metal oxides that may find application in catalysis.
\end{abstract}

(C) 2006 Elsevier Inc. All rights reserved.

Keywords: Mesostructured; Liquid crystals; Transition metal ions; Non-ionic surfactants; Pluronics

\section{Introduction}

Since the first reports $[1,2]$ on the synthesis of mesoporous molecular sieves (designated as M41S) that have welldefined channels and uniform pore sizes, there have been extensive efforts towards the synthesis of new functional materials [3-5] and towards the understanding of the formation mechanism of mesoporous silica materials [6-8]. A liquid crystal templating (LCT) mechanism for the M41S family, particularly MCM-41, was proposed due to the similarity between the liquid crystalline surfactant assemblies and M41S family [6]. Later a generalized liquid crystalline templating mechanism $[7,8]$ was suggested based

\footnotetext{
* Corresponding author. Tel.: +90 312290 3918; fax: +90 3122664579. E-mail address: dag@fen.bilkent.edu.tr (Ö. Dag).
}

on the electrostatic interaction of inorganic species and the head groups of the surfactant molecules. The lyotropic liquid crystalline mesophase of an oligo(ethylene oxide) surfactant was first used by Attard et al. for the synthesis mesoporous silica monoliths [9]. In this assembly process, the silica source, tetramethylorthosilicate (TMOS) was directly added into the previously existing LC mesophase to produce mesostructured silica. In this method, the existence of the LC mesophase is more important than the interaction of the silica precursors and the surfactant cooperation to form the mesophase.

Stucky et al. introduced a family of highly ordered mesoporous silica using oligo(ethylene oxide) type non-ionic surfactants $\left(\mathrm{C}_{n} \mathrm{H}_{2 n+1}\left(\mathrm{OCH}_{2} \mathrm{CH}_{2}\right)_{m} \mathrm{OH}\right.$, denoted as $\left.\mathrm{C}_{n} \mathrm{EO}_{m}\right)$ and triblock poly(ethylene oxide)-poly(propylene oxide)poly(ethylene oxide) (PEO-PPO-PEO) copolymers, pluronics in an acidic media [10]. They found that the non-ionic 
surfactants frequently form cubic or 3D hexagonal mesoporous silica structures, whereas the non-ionic triblock copolymers tend to form $2 \mathrm{D}$ hexagonal $(p 6 \mathrm{~mm})$ mesoporous silica structures. In the pluronic system, the $\mathrm{EO} / \mathrm{PO}$ ratio of the copolymers is an important parameter; decreasing this ratio of the triblock copolymer leads to the formation of lamella mesostructured silica, while increasing it promotes cubic mesostructured silica formation [10]. Göltner and co-workers [11] showed that nonionic amphiphilic diblock copolymers with a polyethylene oxide head group and a polystyrene tail group could also be used as a template to create crack-free mesoporous silica monoliths. Note also that the $\mathrm{C}_{n} \mathrm{EO}_{m}$ type surfactants have been successfully applied to prepare mesoporous transition metal oxides that are not accessible using the electrostatic templating method [12-14]. The metal alkoxides that readily hydrolyze to the corresponding metal oxide can also be templated using $\mathrm{C}_{n} \mathrm{EO}_{m}$ type non-ionic surfactants $[12,13]$.

A new lyotropic liquid crystalline (LLC) mesophase that only contains $\mathrm{C}_{n} \mathrm{EO}_{m}$ surfactant and transition metal salts (TMS) (without water) [15] has recently been introduced by our group. In this binary system, the transition metal aqua complexes induce the $\mathrm{C}_{n} \mathrm{EO}_{m}$ surfactants to self-assemble into an LC mesophase, which is stable for years [15]. The structure of the $\left[\mathrm{M}\left(\mathrm{H}_{2} \mathrm{O}\right)_{x}\right]\left(\mathrm{NO}_{3}\right)_{2}: \mathrm{C}_{n} \mathrm{EO}_{m}$ binary mesophases usually display a $2 \mathrm{D}$ hexagonal mesostructure in nitrate salt systems and a cubic mesostructure in the $\left[\mathrm{M}\left(\mathrm{H}_{2} \mathrm{O}\right)_{x}\right]-$ $\left(\mathrm{ClO}_{4}\right)_{2}: \mathrm{C}_{n} \mathrm{EO}_{m}$ systems [16]. However, the binary chloride salt systems do not have the mesophase. Indeed the chloride TMSs are almost insoluble in the oligo(ethylene oxide) surfactant media [16].

Usually an electrolyte is added to improve the structural properties of the materials [17]. The addition of electrolytes is also known to affect the structure of the LC mesophases [18-22]. This effect has been known for more than a hundred years as the Hofmeister effect [23]. Anions such as $\mathrm{SO}_{4}^{2-}$ and $\mathrm{Cl}^{-}$that decrease the solubility of the surfactants are known as "salting-out" anions, water structure-makers or cosmotropic ions and the others such as $\mathrm{NO}_{3}^{-}$and $\mathrm{ClO}_{4}^{-}$that increase the solubility of the surfactants are known as "salting-in" anions, water-structure-breakers, or chaotropic anions [24]. Note that the electrolytes are almost always present in the synthesis of mesoporous materials. Salts are known to have a significant effect on the formation mechanism of mesoporous materials. Electrolytes generally increase the stability of the materials by improving the interface properties. Ryoo and Jun [25] have improved the stability of mesoporous silica by using various salts. Stucky et al. [26] found that the addition of extra salt stimulates the formation of single crystal materials instead of amorphous materials.

In this work we have studied the effect of salt type and amount on the synthesis of mesostructured silica films and monoliths, produced by LCT approach using $\mathrm{C}_{n} \mathrm{EO}_{m}$ and Pluronics and transition metal salts. The resulting materials were characterized using diffraction (XRD), microscopy (POM and TEM), and spectroscopy (FT-IR and micro-Raman) techniques.

\section{Experimental}

All chemicals and solvents were reagent grade and used as received without any further treatment. The triblock copolymers, poly(ethylene oxide)-poly(propylene oxide)poly(ethylene oxide) (EO-PO-EO), P65 ( $\mathrm{PEO}_{20} \mathrm{PPO}_{30^{-}}$ $\left.\mathrm{PEO}_{20}, \quad M_{\mathrm{av}}=3500\right)$ and $\mathrm{P} 123 \quad\left(\mathrm{PEO}_{20} \mathrm{PPO}_{70} \mathrm{PEO}_{20}\right.$, $M_{\mathrm{av}}=5800$ ) were generously donated by BASF Corp. and used without further treatment. Cobalt(II)nitrate hexahydrate $\left(\left[\mathrm{Co}\left(\mathrm{H}_{2} \mathrm{O}\right)_{6}\right]\left(\mathrm{NO}_{3}\right)_{2}\right), 98 \%$ pure $)$, cobalt(II)chloride hexahydrate $\left(\left[\mathrm{Co}\left(\mathrm{H}_{2} \mathrm{O}\right)_{6}\right] \mathrm{Cl}_{2}, 98 \%\right.$ pure $)$, cobalt(II)perchlorate hexahydrate $\left(\left[\mathrm{Co}\left(\mathrm{H}_{2} \mathrm{O}\right)_{6}\right]\left(\mathrm{ClO}_{4}\right)_{2}\right)$, zinc(II)nitrate hexahydrate $\left(\left[\mathrm{Zn}\left(\mathrm{H}_{2} \mathrm{O}\right)_{6}\right]\left(\mathrm{NO}_{3}\right)_{2}\right)$ and zinc(II)perchlorate hexahydrate $\left(\left[\mathrm{Zn}\left(\mathrm{H}_{2} \mathrm{O}\right)_{6}\right]\left(\mathrm{ClO}_{4}\right)_{2}\right)$ were obtained from Aldrich, Germany. $\mathrm{HNO}_{3}$ and $\mathrm{HClO}_{4}$ were obtained from Aldrich, Germany. Tetramethylorthosilicate (TMOS, \%98 pure) was obtained from Aldrich and Fluka.

\subsection{Preparation of liquid crystalline mesophases with transition metal salts}

The surfactant:water:metal salt samples were prepared either by mixing $1.0 \mathrm{~g}$ of $\mathrm{C}_{12} \mathrm{EO}_{10}$ with $1.0 \mathrm{~g}$ of water and then adding the transition metal salt (TMS) complexes to the mixture, or the TMS was first dissolved in water and then the surfactant was added to the mixture. The mixture was homogenized by a few heating (to the melting point) and cooling (to room temperature (RT)) cycles. The TMS/surfactant mole ratios was varied from 0.0 to 15.0. These samples were either examined in their LC mesophases or used further in the synthesis of mesostructured silica.

\subsection{Synthesis of mesoporous silica by liquid crystalline templating ( LCT)}

A mixture containing $1.0 \mathrm{~g}$ deionized water, $x \mathrm{~g}$ TMS $(x$ was varied between TMS $/ \mathrm{C}_{12} \mathrm{EO}_{10}$ mole ratio of 0.0 and 4.0), $\mathrm{HX}(0.1 \mathrm{~g})$ (acid, $\mathrm{X}=\mathrm{NO}_{3}^{-}, \mathrm{ClO}_{4}^{-}$or $\left.\mathrm{Cl}^{-}\right)$and $1.0 \mathrm{~g}$ $\mathrm{C}_{12} \mathrm{EO}_{10}$ was prepared by first dissolving TMS in deionized water containing $\mathrm{HX}$. Upon addition of $\mathrm{C}_{12} \mathrm{EO}_{10}$, the mixture was homogenized by heating at around $60{ }^{\circ} \mathrm{C}$ for a few minutes to get a clear solution (note also that the mixture is a paste at low salt concentrations and a solution at higher salt concentrations). To the clear mixture, $1.7 \mathrm{~g}$ tetramethylorthosilicate (TMOS) was added at once. The mixture became a clear solution upon shaking the mixture for a few minutes or gentle heating over a hot plate. The nitric acid $\left(\mathrm{HNO}_{3}\right)$, perchloric acid $\left(\mathrm{HClO}_{4}\right)$ and hydrochloric acid $(\mathrm{HCl})$ have been used as acid sources to speed up the silica polymerizations in the metal nitrate, metal perchlorate and metal chloride systems, respectively.

Water $(3.0 \mathrm{~g}), x \mathrm{~g}$ TMS $(x$ corresponds to TMS/P123 mole ratios of $0.0-9.0$ ), $0.1 \mathrm{~g} \mathrm{HX}$ (acid, $\mathrm{X}=\mathrm{NO}_{3}^{-}, \mathrm{ClO}_{4}^{-}$ or $\mathrm{Cl}^{-}$) and $1.0 \mathrm{~g} \mathrm{P} 123$ or $\mathrm{P} 65$ were mixed in the same order as in $\mathrm{C}_{12} \mathrm{EO}_{10}$ case. Then, the mixture was homogenized by stirring with a magnetic stirrer for $15 \mathrm{~min}$, and then $1.7 \mathrm{~g}$ of TMOS was added as the silica source. The clear solutions 
were spread on glass slides to produce monoliths. The film samples were obtained by dip coating of the clear mixturesthat were prepared using $10 \mathrm{~g}$ of water-on glass or silicon wafers with a pulling speed of $1.0 \mathrm{~mm} / \mathrm{s}$. The film and/or monolith samples were crushed to obtain a fine powder. The powder samples were calcined in steps from RT to $500{ }^{\circ} \mathrm{C}$. The powder X-ray diffraction (PXRD) patterns were recorded at various temperatures using the samples heated step by step (step 1: from RT to $200^{\circ} \mathrm{C}$ in $2 \mathrm{~h}$ then to RT, step 2: from RT to $300{ }^{\circ} \mathrm{C}$ in $3 \mathrm{~h}$, kept at $300^{\circ} \mathrm{C}$ for $1 \mathrm{~h}$ and then cooled to RT, step 3: heated from RT to $500{ }^{\circ} \mathrm{C}$ in $5 \mathrm{~h}$ and kept at $500{ }^{\circ} \mathrm{C}$ for $5 \mathrm{~h}$ ).

\subsection{Characterization}

Polarized optical microscopy (POM) images were recorded in transmittance mode on a Meije techno ML 9400 series Polarizing Microscope with transmitted light illumination, using convergent white light between parallel and cross polarizers. The X-ray diffraction (XRD) patterns were collected on a Rigaku Miniflex diffractometer using a high power $\mathrm{Cu}-\mathrm{K}_{\alpha}$ source operating at $30 \mathrm{kV} / 15 \mathrm{~mA}$. The XRD patterns of a sample were collected at least twice in the $1-52 \theta$ range with a scan rate of $0.5^{\circ} / \mathrm{min}$. The transmission FT-IR spectra were recorded with a Bomem Hartman MB-102 model FT-IR spectrometer. A standard DTGS detector was used with a resolution of $4 \mathrm{~cm}^{-1}$ and a 32 scan for all samples. The samples were prepared as thin films over a $\mathrm{Si}(100)$ wafer or sandwiched between two wafers. The micro-Raman spectra were recorded on a LabRam confocal Raman microscope with a $300 \mathrm{~mm}$ focal length. The spectrometer is equipped with a $\mathrm{HeNe}$ laser operated at $20 \mathrm{~mW}$, polarized 500:1 with a wavelength of $632.817 \mathrm{~nm}$, and a $1024 \times 256$ element CCD camera. TEM images of all samples were recorded on a Hitachi HD-2000 STEM operating at $200 \mathrm{kV}$ and $30 \mathrm{~mA}$. The samples were prepared by dispersing the powder/fragments onto a carbon film-supported 200 mesh copper grid.

\section{Results and discussion}

\subsection{The LC transition metal salts: $C_{n} E O_{m}$ and synthesis of mesostructured silica}

The LC mesophases $[15,27]$ of $\mathrm{C}_{12} \mathrm{EO}_{10}$ and pluronics with some transition metal salts, $\left[\mathrm{M}\left(\mathrm{H}_{2} \mathrm{O}\right)_{6}\right] \mathrm{X}_{2} \quad(\mathrm{M}=$ $\mathrm{Co}(\mathrm{II}), \mathrm{Zn}(\mathrm{II})$ and $\mathrm{X}=\mathrm{NO}_{3}^{-}, \mathrm{Cl}^{-}$and $\mathrm{ClO}_{4}^{-}$) were used as template in the synthesis of mesostructured silica. The silica polymerization takes place in the hydrophilic regions of the LC mesophase. We have studied intensively the solid phase formed from the mixture of $\left[\mathrm{Co}\left(\mathrm{H}_{2} \mathrm{O}\right)_{6}\right]-$ $\left(\mathrm{NO}_{3}\right)_{2}, \quad\left[\mathrm{Co}\left(\mathrm{H}_{2} \mathrm{O}\right)_{6}\right] \mathrm{Cl}_{2}, \quad\left[\mathrm{Co}\left(\mathrm{H}_{2} \mathrm{O}\right)_{6}\right]\left(\mathrm{ClO}_{4}\right)_{2}$ transition metal salts, oligo(ethylene oxide) non-ionic surfactant and Pluronics $\left(\mathrm{PEO}_{x} \mathrm{PPO}_{y} \mathrm{PEO}_{x}\right)$, acid and TMOS.

In this work, the salt concentration and salt type were used as reaction parameters and were monitored using POM. A fan-like texture (characteristic to 3D hexagonal

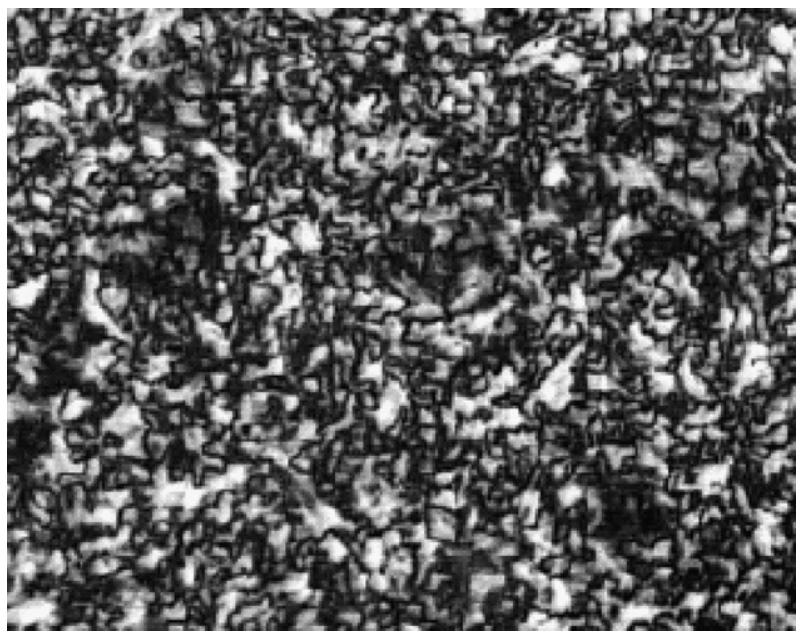

Fig. 1. The POM image of the $\left[\mathrm{Co}\left(\mathrm{H}_{2} \mathrm{O}\right)_{6}\right]\left(\mathrm{NO}_{3}\right)_{2}-\mathrm{C}_{12} \mathrm{EO}_{10}-\mathrm{mesoSiO}_{2}$ sample with a salt/surfactant mole ratio of 0.4 .

structure, see also the text related to XRD below) is observed in the salt free samples and in the $\left[\mathrm{Co}\left(\mathrm{H}_{2} \mathrm{O}\right)_{6}\right]-$ $\left(\mathrm{NO}_{3}\right)_{2}-\mathrm{C}_{12} \mathrm{EO}_{10}-\mathrm{mesoSiO}{ }_{2}$ samples with a salt/surfactant mole ratio up to 1.2, Fig. 1. However the images are dark in samples with a salt/surfactant mole ratio of 1.6 and above. This means that the structure is hexagonal up to a mole ratio of 1.2 and it is converted to cubic above a mole ratio of 1.2 (or a disordered amorphous phase). However, the mesostructured silica samples are stable up to a $2.0 \mathrm{~mol}$ ratio without leaching out salt ions $\left(\mathrm{ca} . \mathrm{Co}^{2+} /\right.$ $\mathrm{SiO}_{2}=0.28$ ). Above mole ratios of 2.0 , the salt ions slowly crystallize and separate out from the mesophase in a few days. Over a mole ratio of $4.0\left(\mathrm{ca} . \mathrm{Co}^{2+} / \mathrm{SiO}_{2}=0.56\right)$, the crystallization process of salt ions takes only $1 \mathrm{~h}$. Since the LC mesophase has been used as a reaction medium for the synthesis of mesostructured silica materials, the LC mesophases of salt:surfactant systems were also studied in detail. The salt systems, such as $\left[\mathrm{Co}\left(\mathrm{H}_{2} \mathrm{O}\right)_{6}\right]\left(\mathrm{NO}_{3}\right)_{2}$ : $\mathrm{C}_{12} \mathrm{EO}_{10}$ with or without water forms an LC mesophase that displays a fan texture up to salt/surfactant mole ratio of $3.0[15,16,28,29]$. Above a mole ratio of 3.0 the TMS: $\mathrm{C}_{12} \mathrm{EO}_{10}$ LC systems undergo phase change from $2 \mathrm{D}$ hexagonal to cubic. However, the mesostructured silica obtained from a $\left[\mathrm{Co}\left(\mathrm{H}_{2} \mathrm{O}\right)_{6}\right]\left(\mathrm{NO}_{3}\right)_{2}: \mathrm{C}_{12} \mathrm{EO}_{10}: \mathrm{HNO}_{3}: \mathrm{TMOS}$ mixture undergoes structural changes from hexagonal to cubic at around a salt/surfactant mole ratio of 1.2. Since the phase change takes place at relatively lower salt concentrations in the mesostructured silica systems, the silica species also acts as hydrophilic species and mimic the salt ions. Based on our data it can be generalized that there is a phase boundary between the hydrophilic and hydrophobic regions that is controlled by a thermodynamic variable (notionally hydrophilicity), therefore it leads to a transition at higher salt concentrations. Increasing the hydrophilic content with respect to hydrophobic content changes the hexagonal mesophase to the cubic mesophase. The reverse, from cubic to hexagonal phase change is also possible if we 
decrease the hydrophilic content (or increase the hydrophobic content).

A series of POM images from $\left[\mathrm{Co}\left(\mathrm{H}_{2} \mathrm{O}\right)_{6}\right]\left(\mathrm{ClO}_{4}\right)_{2}$ : $\mathrm{C}_{12} \mathrm{EO}_{10}: \mathrm{HClO}_{4}: \mathrm{TMOS}$ systems were also recorded, where the image for salt free sample is birefringent. The POM images of the mesostructured silica with $0.2\left[\mathrm{Co}\left(\mathrm{H}_{2} \mathrm{O}\right)_{6}\right]-$ $\left(\mathrm{ClO}_{4}\right)_{2} / \mathrm{C}_{12} \mathrm{EO}_{10}$ and higher mole ratios became dark between the crossed polarizers. Notice also that in the salt free silica materials (there are still $\mathrm{ClO}_{4}^{-}$anions coming from $0.1 \mathrm{~g}$ of $\mathrm{HClO}_{4}$ acid) are still birefringent and the addition of small amounts of $\left[\mathrm{Co}\left(\mathrm{H}_{2} \mathrm{O}\right)_{6}\right]\left(\mathrm{ClO}_{4}\right)_{2}$ salt makes the image dark. Above a $1.0 \mathrm{~mol}$ ratio the perchlorate salt ions crystallize out from mesostructured silica after about $2 \mathrm{~h}$ of aging. It could be concluded that (see also the XRD part) the perchlorate salt ions make the silica films and monoliths undergo a phase change from hexagonal to cubic at a salt/surfactant mole ratio as low as 0.2 . This shows that the $\mathrm{ClO}_{4}^{-}$ion makes the media more hydrophilic than the $\mathrm{NO}_{3}^{-}$ion. However, according to the Hofmeister series, the $\mathrm{ClO}_{4}^{-}$anion is more salting-in than the $\mathrm{NO}_{3}^{-}$ anion, therefore $\mathrm{ClO}_{4}^{-}$anion would be expected to be more soluble than the $\mathrm{NO}_{3}^{-}$anion. It is a well known fact that the nitrate ion is a better ligand than the perchlorate ion. The coordination of the nitrate ion to the metal ion lowers the ion and charge density in the media and enhances the solubility of transition metal nitrate salts (see FTIR and
Raman part) [16]. As the salt concentration or the ionic strength of the mixture increases, the structure tends to change from a hexagonal (normal 3D) to cubic (V1) phase to accommodate the excess ions and charge in the hydrophilic domains of the mesophase. The silica species, which form during hydrolysis and polymerization of the silica source, also resemble the salt ions in the media. Adding the silica species increases the hydrophilic content of the mixture.

The silica monoliths prepared from $\left[\mathrm{Co}\left(\mathrm{H}_{2} \mathrm{O}\right)_{6}\right]\left(\mathrm{NO}_{3}\right)_{2}$ salt, $\mathrm{C}_{12} \mathrm{EO}_{10}$ surfactant, $\mathrm{HNO}_{3}$ and TMOS in varying salt concentrations were also characterized using XRD (Fig. 2). The XRD patterns of the salt-free sample and samples up to a $0.2 \mathrm{~mol}$ ratio display two major lines, one at around $2^{\circ}$ and the other at around $4^{\circ}$, Fig. 2(A). However, the sample with a salt/surfactant mole ratio of 0.4 displays more diffraction lines, Fig. 2(B). The diffraction pattern of the salt-free samples and samples with 0.4 and up to $1.2 \mathrm{~mol}$ ratios can be indexed to a $3 \mathrm{D}$ hexagonal structure of $\mathrm{P}_{3} / \mathrm{mmc}$ space group with $c / a$ parameter of $1.632(a=$ $52.5 \AA$ and $c=85.7 \AA$ ). However, the patterns of the samples above a $1.2 \mathrm{~mol}$ are indexed to a cubic structure. Fig. 2(C) shows a diffraction pattern of a sample with a salt/surfactant mole ratio of 2.0 that displays lines at 45.2, 40.4, 36.9, and $24.2 \AA$, due to (200), (210), (211), and (321) planes, respectively, of a cubic, Pm3n space
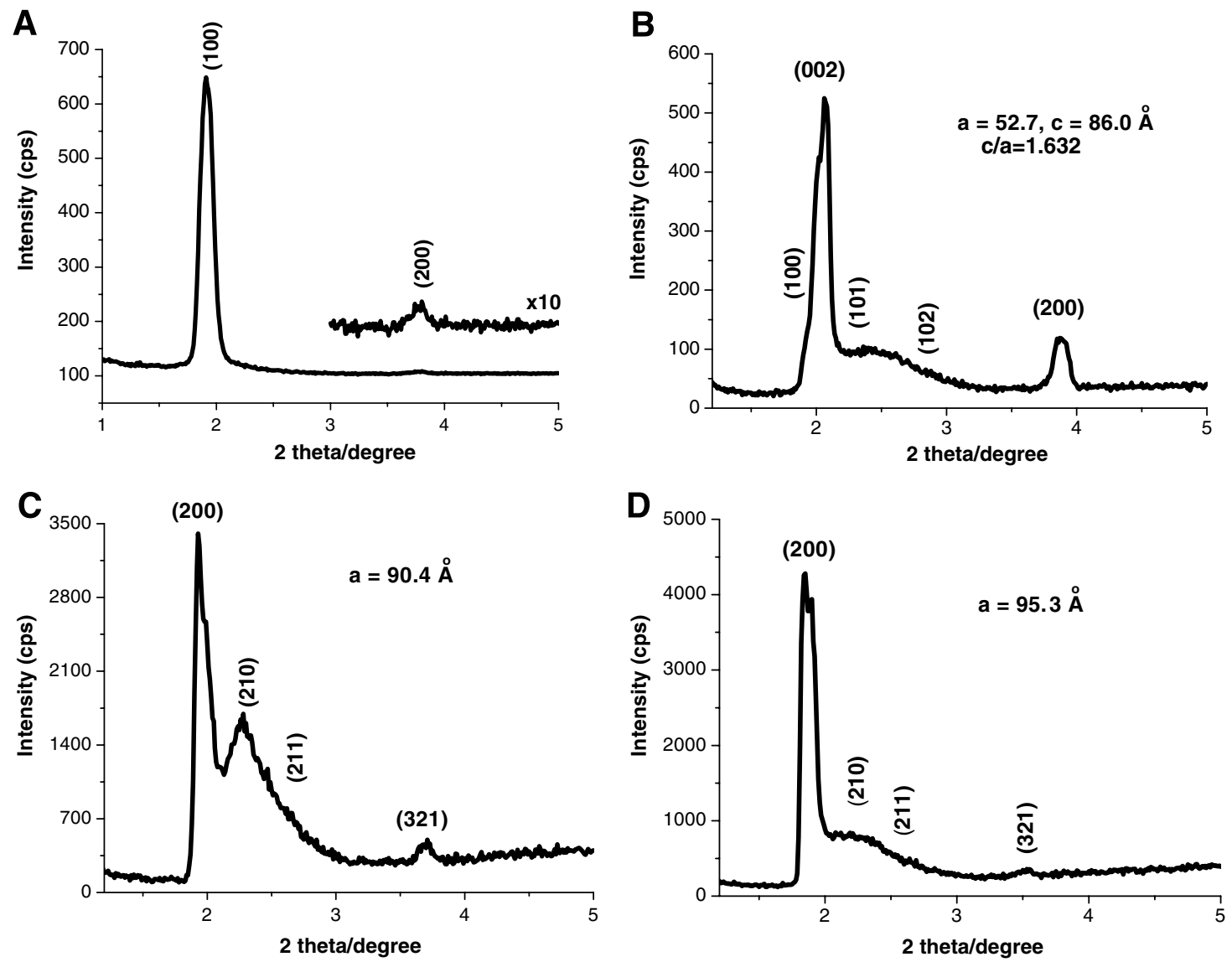

Fig. 2. The XRD patterns of $\left[\mathrm{Co}\left(\mathrm{H}_{2} \mathrm{O}\right)_{6}\right]\left(\mathrm{NO}_{3}\right)_{2}-\mathrm{C}_{12} \mathrm{EO}_{10}-\mathrm{mesoSiO}_{2}$ with varying salt/surfactant mole ratios of, (A) 0.0, (B) 0.4, (C) 2.0, and (D) 3.0. 
group. Above a 3.0 mol ratio the cubic phase is still preserved but the excess salt crystallizes out, Fig. 2(D).

We have also investigated the $\left[\mathrm{Co}\left(\mathrm{H}_{2} \mathrm{O}\right)_{6}\right]\left(\mathrm{ClO}_{4}\right)_{2-}$ $\mathrm{C}_{12} \mathrm{EO}_{10}-\mathrm{mesoSiO}_{2}$ samples of the salt/surfactant mole ratios of $0.2,0.4,0.6,0.8,1.0,2.0$ and 3.0 using XRD. The $\left[\mathrm{Co}\left(\mathrm{H}_{2} \mathrm{O}\right)_{6}\right]\left(\mathrm{ClO}_{4}\right)_{2}-\mathrm{C}_{12} \mathrm{EO}_{10}-\mathrm{mesoSiO}_{2}$ samples are found to be stable up to 1.0 salt/surfactant mole ratio. Above a $1.0 \mathrm{~mol}$ ratio, the salt crystallizes out and the mesophase disappears above a $2.0 \mathrm{~mol}$ ratio. The XRD patterns become broader with a mole ratio over 0.4, Fig. 3(A). Also note that $\mathrm{HClO}_{4}$ acid was used as a catalyst in the synthesis of these samples, therefore the reaction mixture already had the perchlorate ion before adding the perchlorate salt. The effect of the $\mathrm{ClO}_{4}^{-}$ion of the acid was investigated by changing the amount of acid in the salt free samples (1.00 $\mathrm{g}$ water, $1.00 \mathrm{~g}$ surfactant, $1.70 \mathrm{~g}$ TMOS and various amount of $\mathrm{HClO}_{4}$ between 0.00 and $0.10 \mathrm{~g}$ ). The amount of acid is important because it determines
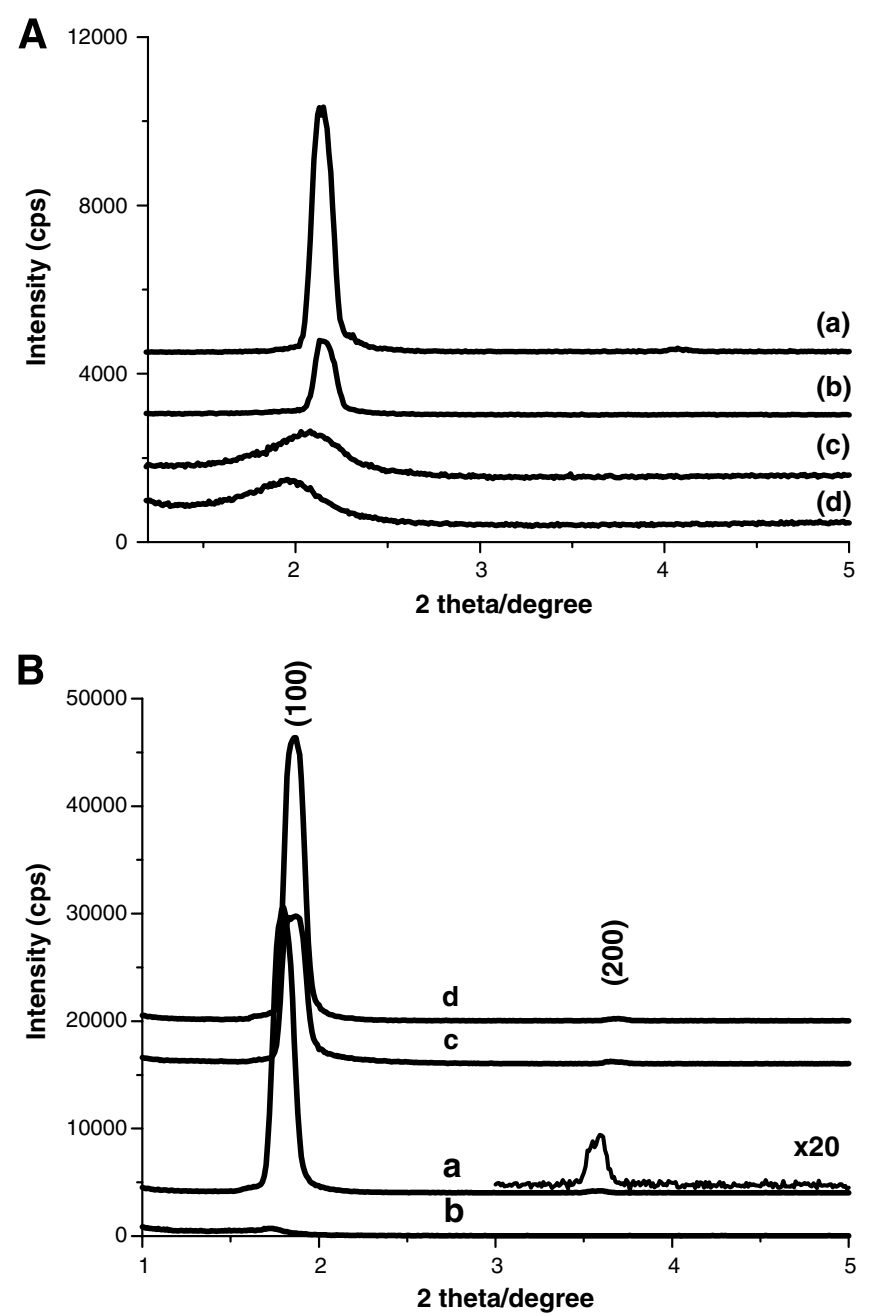

Fig. 3. The XRD patterns of (A) 1 day aged $\left[\mathrm{Co}\left(\mathrm{H}_{2} \mathrm{O}\right)_{6}\right]\left(\mathrm{ClO}_{4}\right)_{2}-\mathrm{C}_{12} \mathrm{EO}_{10^{-}}$ mesoSiO $\mathrm{S}_{2}$ samples with salt/surfactant mole ratios of (a) 0.2 , (b) 0.4 , (c) 0.6 , and (e) 1.0 and (B) salt free-samples of $\mathrm{C}_{12} \mathrm{EO}_{10}: \mathrm{HClO}_{4}$ :TMOS system with $0.03 \mathrm{~g} \mathrm{HClO}_{4}$ by time (a) immediately and (b) $2 \mathrm{~h}$ after preparation and with $0.1 \mathrm{~g}^{\mathrm{HClO}_{4}}$ by time (c) immediately and (d) 1 day after preparation. the rate of the silica polymerization. If the silica polymerization is slow, the mesophase collapses as water evaporates, so the silica polymerization cannot be templated by the LC phase and eventually the silica becomes disordered.

In the case of 0.03 and $0.06 \mathrm{~g}$ of acid, the polymerization process is not fast enough so that the texture under POM is first birefringent, but after some time $(\sim 20 \mathrm{~min})$ it turns dark. The diffraction line, which is very sharp at initial stages of the reactions, also becomes broader after $20 \mathrm{~min}$. The early structure is due to the LC mesophase (intermediate phase) of the mixture and as a result, we observe a fan texture under POM and a sharp diffraction line. As the water evaporates, the LC mesophase collapses and the silica framework becomes disordered, therefore the XRD patterns become broader over time (see Fig. 3(B)) and the POM images become dark. As the acid concentration reaches to $0.10 \mathrm{~g}$ of $\mathrm{HClO}_{4}$ acid, a sharp XRD diffraction lines due to the (100) and (200) planes of an oriented hexagonal structure and the bright fan texture in the POM images stay indefinitely, Fig. 3(B).

The $\left[\mathrm{Co}\left(\mathrm{H}_{2} \mathrm{O}\right)_{6}\right]\left(\mathrm{NO}_{3}\right)_{2}-\mathrm{C}_{12} \mathrm{EO}_{10}-$ mesoSiO$_{2}$ film samples were prepared by dip-coating and investigated using the XRD technique and FTIR spectroscopy. Extra $9.0 \mathrm{~g}$ of water was added to the mixture of TMS: $\mathrm{H}_{2} \mathrm{O}: \mathrm{HNO}_{3}$ : $\mathrm{C}_{\mathrm{n}} \mathrm{EO}_{\mathrm{m}}$ :TMOS to dilute the solution for dip-coating. The mesostructured silica was placed as a very thin film on the microscope slides and silicon wafers. The XRD pattern of the film samples displays a very sharp and intense single line (not shown) up to salt/surfactant mole ratio of 3.5. It is difficult to make any assignments for the structure of the film samples. However, the thin films were used mainly to investigate the spectroscopic properties of the samples.

Although the $\mathrm{NO}_{3}^{-}$ion is less salting-in than the $\mathrm{ClO}_{4}^{-}$ ion according to the Hofmeister series, nitrate salts are more soluble in our reaction medium than perchlorate salts [16]. If salts were alkali metal salts instead of TMSs, most likely there would be no deviation from the Hofmeister series. The coordination of the $\mathrm{NO}_{3}^{-}$ion to the transition metal cation is a key parameter for this deviation from the Hofmeister series. The coordination of the $\mathrm{NO}_{3}^{-}$ion to a transition metal cation can be easily detected using FT-IR and micro-Raman spectroscopy. Fig. 4(A) shows a series of FT-IR spectra of a $\left[\mathrm{Co}\left(\mathrm{H}_{2} \mathrm{O}\right)_{6}\right]\left(\mathrm{NO}_{3}\right)_{2}$ $\mathrm{C}_{12} \mathrm{EO}_{10}-$ mesoSiO$_{2}$ sample with 1.2 salt/surfactant mole ratio, recorded immediately, $3 \mathrm{~h}$ after preparation and 1 day after preparation. The fresh sample display a broad peak at around $1365 \mathrm{~cm}^{-1}$ assigned to the degenerate asymmetric stretching of the free nitrate ion in the media. Note also that the spectrum of a solution of a nitrate salt is very similar in this region. The coordination of the nitrate ion to a metal cation lowers the symmetry of the free nitrate ion from the $D_{3 \mathrm{~h}}$ to $C_{2 \mathrm{v}}$ point group. Therefore, the degeneracy of IR active $E$ modes of the free nitrate ion (asymmetric stretching modes) is lifted and split into two non-degenerate IR-active $\mathrm{B}_{2}$ and $\mathrm{A}_{1}$ modes [29]. Therefore, two extra peaks are observed around the free nitrate ion frequency region in the IR spectra. The FT-IR spectra of 

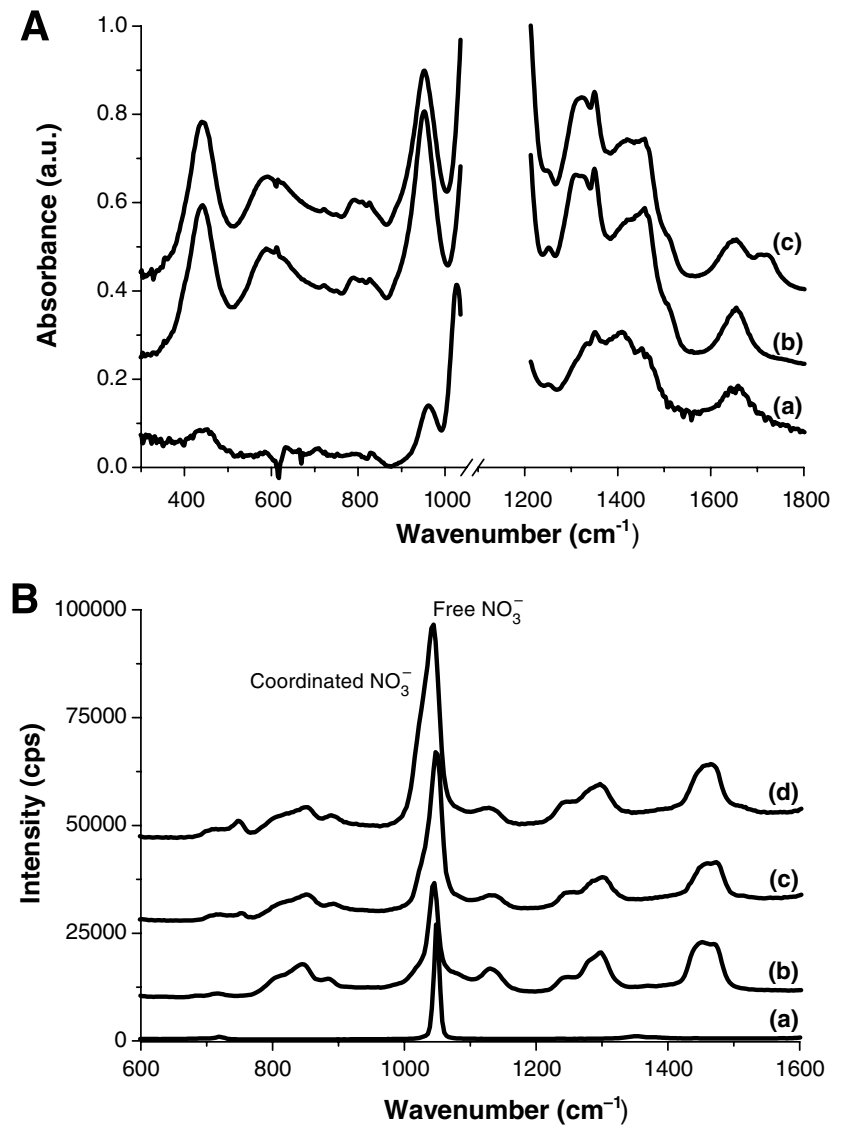

Fig. 4. (A) The FT-IR spectra of $\left[\mathrm{Co}\left(\mathrm{H}_{2} \mathrm{O}\right)_{6}\right]\left(\mathrm{NO}_{3}\right)_{2}-\mathrm{C}_{12} \mathrm{EO}_{10}-\mathrm{mesoSiO}_{2}$ samples with 1.2 salt/surfactant ratio at different stages of the polymerization process: (a) immediately after preparation, (b) $3 \mathrm{~h}$ after preparation and (c) 1 day after preparation. (B) The micro-Raman Spectra of (a) $\left[\mathrm{Co}\left(\mathrm{H}_{2} \mathrm{O}\right)_{6}\right]\left(\mathrm{NO}_{3}\right)_{2}$ crystals and $\left[\mathrm{Co}\left(\mathrm{H}_{2} \mathrm{O}\right)_{6}\right]\left(\mathrm{NO}_{3}\right)_{2}-\mathrm{C}_{12} \mathrm{EO}_{10}$-mesoSiO${ }_{2}$ films with salt/surfactant mole ratios of (b) 0.6 , (c) 1.4 and (d) 1.6 .

$\left[\mathrm{Co}\left(\mathrm{H}_{2} \mathrm{O}\right)_{6}\right]\left(\mathrm{NO}_{3}\right)_{2}-\mathrm{C}_{12} \mathrm{EO}_{10}-\mathrm{mesoSiO}_{2}$ display two nitrate peaks, at 1317 and $1460 \mathrm{~cm}^{-1}$ and a shoulder, at around $1500 \mathrm{~cm}^{-1}$ over time in addition to the free nitrate peak around $1365 \mathrm{~cm}^{-1}$, Fig. 4(A). Fig. 4(B) shows microRaman spectrum of a $\left[\mathrm{Co}\left(\mathrm{H}_{2} \mathrm{O}\right)_{6}\right]\left(\mathrm{NO}_{3}\right)_{2}$ crystal as a reference and spectra of $\left[\mathrm{Co}\left(\mathrm{H}_{2} \mathrm{O}\right)_{6}\right]\left(\mathrm{NO}_{3}\right)_{2}-\mathrm{C}_{12} \mathrm{EO}_{10}-$ mesoSiO$_{2}$ samples with various salt/surfactant mole ratios. The free nitrate symmetric stretching mode is observed at $1042 \mathrm{~cm}^{-1}$. As the salt concentration increases a shoulder that originates from the coordinated $\mathrm{NO}_{3}^{-}$species appears [16]. The symmetric stretching mode of the coordinated nitrate species also becomes IR active and is observed at around $1020 \mathrm{~cm}^{-1}$ in the FT-IR spectra. However, in the silica system, the $\delta$-Si-O-H bending mode strongly absorbs in the same region. The sharp peak at around $952 \mathrm{~cm}^{-1}$ is due to the $\delta-\mathrm{Si}-\mathrm{O}-\mathrm{H}$ and the symmetric stretching of the coordinated nitrate ion, Fig. 4(A).

In the literature, it is known that the forces (hydrophobic) that hold the micelles are due to the organic part of the surfactant molecules. It is also known that adding extra hydrophobic material to the mixture increases the stability of micelles [30]. We investigated this question by increasing the hydrophobic tail of the surfactant molecules to reverse the effect of the salt ions (or the ionic strength). The $\left[\mathrm{Co}\left(\mathrm{H}_{2} \mathrm{O}\right)_{6}\right]\left(\mathrm{NO}_{3}\right)_{2}-\mathrm{C}_{n} \mathrm{EO}_{m}$-mesoSiO $\mathrm{H}_{2}$ samples of two different surfactants $\left(\mathrm{C}_{18} \mathrm{EO}_{10}\right.$ and $\left.\mathrm{C}_{12} \mathrm{EO}_{10}\right)$ with a salt/surfactant mole ratio of 2.0 were prepared and investigated using the POM and XRD techniques. The POM image of $\left[\mathrm{Co}\left(\mathrm{H}_{2} \mathrm{O}\right)_{6}\right]\left(\mathrm{NO}_{3}\right)_{2}-\mathrm{C}_{12} \mathrm{EO}_{10}$-mesoSiO ${ }_{2}$ sample is dark. However the image of the $\left[\mathrm{Co}\left(\mathrm{H}_{2} \mathrm{O}\right)_{6}\right]\left(\mathrm{NO}_{3}\right)_{2} \mathrm{C}_{18} \mathrm{EO}_{10^{-}}$ mesoSiO $\mathrm{S}_{2}$ sample displayed fan-like textures between the crossed polarizers due to a hexagonal structure. The XRD pattern of the mesostructured silica, obtained using a $\mathrm{C}_{12} \mathrm{EO}_{10}$ surfactant, can be indexed to cubic structure $(a=90.4 \AA)$ with diffraction lines at $45.2,40.4,36.9$, and $24.2 \AA$, due to (200), (210), (211), and (321) planes, respectively, of a cubic, Pm3n space group. However, the diffraction pattern of the mesostructured silica synthesized using the $\mathrm{C}_{18} \mathrm{EO}_{10}$ surfactant is still $3 \mathrm{D}$ hexagonal with unit cell parameters of $a=56.3 \AA, c=91.9 \AA$ and $c / a$ of 1.632 . Therefore, increasing the hydrophilic content (salt concentration) leads to a phase change from hexagonal to cubic, on the other hand increasing organic (hydrophobic) content causes a reverse transformation.

As the hydrophobic content of the media is increased, the mesophase undergoes change from cubic to hexagonal structure and vice versa with increasing the hydrophilic content. The surface of a spherical and/or rod like micelles are hydrophilic (aqua) with an inner hydrophobic (organic) cores. Therefore, TMS ions mostly accumulate on the hydrophilic side of the LC media. As the amount of salt concentration increases, the ion density on the interface between the micelles in the LC media increases. As a response, the molecules in the micelles reorganize to increase their surface area to minimize their energy and adjust their curvature [31] for the right structure type.

\subsection{Mesoporous transition metal salts-pluronics-mesoSiO $\mathrm{S}_{2}$ materials}

Previously, the LC mesophases of pluronics in various media [32,33] including transition metal salts [27], and the synthesis of mesostructured silica [34-37] using pluronics have been extensively investigated. In this section of the text, we summarize our observations of the effect of TMSs in the synthesis of mesostructured silica using P65 and P123. Fig. 5 shows a TEM image of a $\left[\mathrm{Zn}\left(\mathrm{H}_{2} \mathrm{O}\right)_{6}\right]\left(\mathrm{NO}_{3}\right)_{2^{-}}$ P65-mesoSiO ${ }_{2}$ sample at a low salt/P65 mole ratio and a series of XRD patterns recorded from various $\left[\mathrm{Zn}\left(\mathrm{H}_{2} \mathrm{O}\right)_{6}\right]\left(\mathrm{NO}_{3}\right)_{2}-\mathrm{P} 65-\mathrm{mesoSiO}_{2}$ samples with a salt/P65 mole ratio of $0.0-9.0$. The $\left[\mathrm{Zn}\left(\mathrm{H}_{2} \mathrm{O}\right)_{6}\right]\left(\mathrm{NO}_{3}\right)_{2}$-P65-meso$\mathrm{SiO}_{2}$ materials are well ordered at low TMS concentrations (up to a salt/P65 mole ratio of 3.0). The well defined lattice spacing $(7.2 \mathrm{~nm})$ throughout the TEM image is consistent with the XRD patterns. The XRD pattern of the salt free sample and the sample with a mole ratio of 1.0 are very similar with broad lines at $1.27(69.4 \AA)$ with a shoulder at $1.22(72.6 \AA)$ and at $1.23(71.9 \AA)$ with a shoulder at $1.13(77.9 \AA)$, respectively, Fig. 5. The patterns become very broad at a salt/P65 mole ratio of 3.0 and no diffraction 

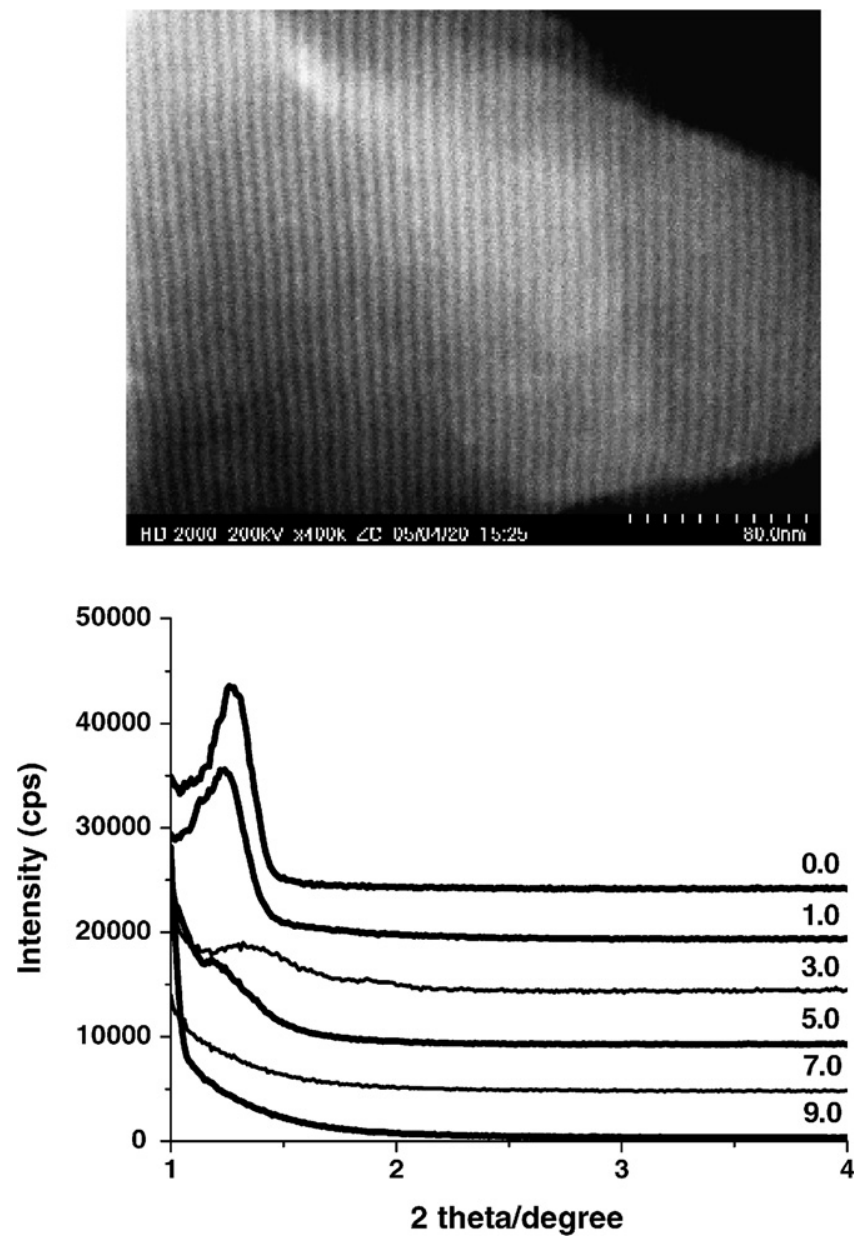

Fig. 5. (Top) TEM image of $1.0\left[\mathrm{Zn}\left(\mathrm{H}_{2} \mathrm{O}\right)_{6}\right]\left(\mathrm{NO}_{3}\right)_{2}-\mathrm{P} 65-\mathrm{mesoSiO}_{2}$ (scale bar is $80 \mathrm{~nm}$ ) and (bottom) XRD patterns of the $\left[\mathrm{Zn}\left(\mathrm{H}_{2} \mathrm{O}\right)_{6}\right]\left(\mathrm{NO}_{3}\right)_{2}-\mathrm{P} 65-$ mesoSiO ${ }_{2}$ samples as the salt-to-P65 mole ratio shown in the plots.

is observed above a mole ratio of 5.0. However in a disordered silica matrix, the salt ions are still soluble at higher concentrations.

The $\left[\mathrm{Zn}\left(\mathrm{H}_{2} \mathrm{O}\right)_{6}\right]\left(\mathrm{NO}_{3}\right)_{2}-\mathrm{P} 123-$ mesoSiO$_{2}$ samples are more ordered compared to $\left[\mathrm{Zn}\left(\mathrm{H}_{2} \mathrm{O}\right)_{6}\right]\left(\mathrm{NO}_{3}\right)_{2}$ - $\mathrm{P} 65$-meso$\mathrm{SiO}_{2}$ samples. The XRD pattern of $\left[\mathrm{Zn}\left(\mathrm{H}_{2} \mathrm{O}\right)_{6}\right]\left(\mathrm{NO}_{3}\right)_{2^{-}}$ $\mathrm{P} 123-\mathrm{mesoSiO}_{2}$ samples display up to five diffraction lines that can be assigned to (100), (200), (300), (400) and (500) lines of a lamella structure with a unit cell parameter $a$ of $100.3 \AA$. Fig. 6 shows the XRD patterns of $\left[\mathrm{Zn}\left(\mathrm{H}_{2} \mathrm{O}\right)_{6}\right]\left(\mathrm{NO}_{3}\right)_{2}-\mathrm{P} 123-$ mesoSiO ${ }_{2}$ samples with salt/P123 mole ratios of 1.0-9.0. This approximately corresponds to the $0.25 \mathrm{TMS} /$ ethoxy group in P123. Note also that the hexagonal to cubic transformation takes place at a ratio of around 0.125 TMS/ethoxy group in $\left[\mathrm{M}\left(\mathrm{H}_{2} \mathrm{O}\right)_{6}\right]\left(\mathrm{NO}_{3}\right)_{2}-\mathrm{C}_{12} \mathrm{EO}_{10}-\mathrm{mesoSiO}_{2}$ materials. Also note that the PO/EO ratio increases by a factor of $70 / 30$ in P123 compared to P65. However, one can dissolve more salts in both the LC TMS:P123 and mesostructured TMS-P123-mesoSiO ${ }_{2}$ by keeping the structural order compared to the LC TMS:P65 and mesostructured TMS-P65mesoSiO ${ }_{2}$. Therefore, the solubility of TMS does not only depend on the number of ethoxy groups, but it also

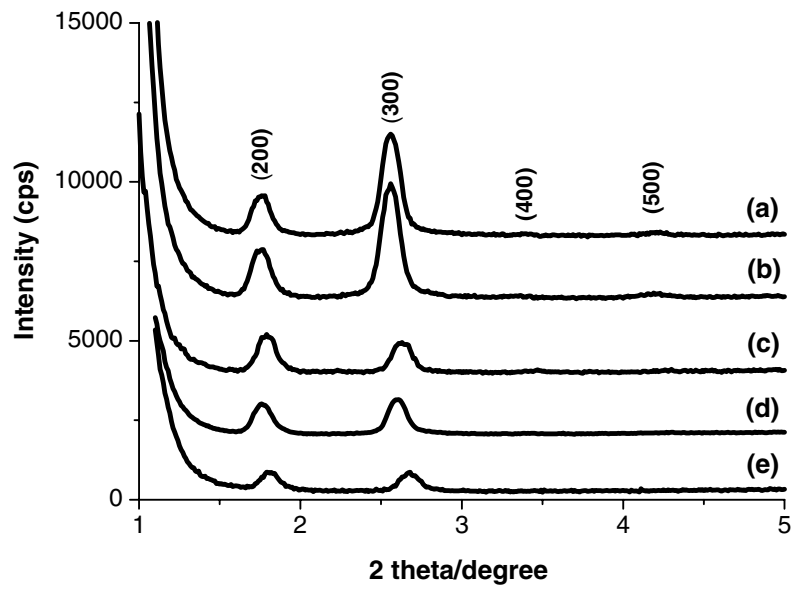

Fig. 6. The XRD patterns of the $\left[\mathrm{Zn}\left(\mathrm{H}_{2} \mathrm{O}\right)_{6}\right]\left(\mathrm{NO}_{3}\right)_{2}-\mathrm{P} 123-\mathrm{mesoSiO}_{2}$ samples with salt/P123 mole ratios of (a) 0.0, (b) 1.0, (c) 5.0, (d) 7.0 and (e) 9.0 .

depends on the hydrophilic free space that is larger in P123 systems in both LC TMS:Pluronics and mesostructured TMS-Pluronics-mesoSiO ${ }_{2}$.

The effect of the transition metal perchlorate salt on the mesostructured TMS-P123-mesoSiO ${ }_{2}$ has also been investigated. Fig. 7 shows a XRD pattern of a $\left[\mathrm{M}\left(\mathrm{H}_{2} \mathrm{O}\right)_{6}\right]\left(\mathrm{NO}_{3}\right)_{2}-$ P123-mesoSiO ${ }_{2}$ sample. The diffraction lines at 78.5, 46.0, and $31.5 \AA d$-spacing of the (110), (211), (222) planes, respectively, originate from a cubic structure with a $\mathrm{P}_{3}$ 32 space group. The plot in the inset of Fig. 7 shows an excellent correlation among the diffraction lines with a slope of $109.1 \AA$ that corresponds to the unit cell parameter, $a$. The lamella structure in the $\left[\mathrm{Zn}\left(\mathrm{H}_{2} \mathrm{O}\right)_{6}\right]-$ $\left(\mathrm{NO}_{3}\right)_{2}-\mathrm{P} 123-\mathrm{mesoSiO}_{2}$ becomes cubic in the $\left[\mathrm{Zn}\left(\mathrm{H}_{2} \mathrm{O}\right)_{6}\right]$ $\left(\mathrm{ClO}_{4}\right)_{2}-\mathrm{P} 123-\mathrm{mesoSiO}$. Thus, the nitrate and perchlorate salts show a similar effect in the TMS-Pluronic-meso$\mathrm{SiO}_{2}$ as observed in the TMS- $\mathrm{C}_{n} \mathrm{EO}_{m}$-mesoSiO ${ }_{2}$ samples. Further TEM imaging, XRD and spectroscopy studies

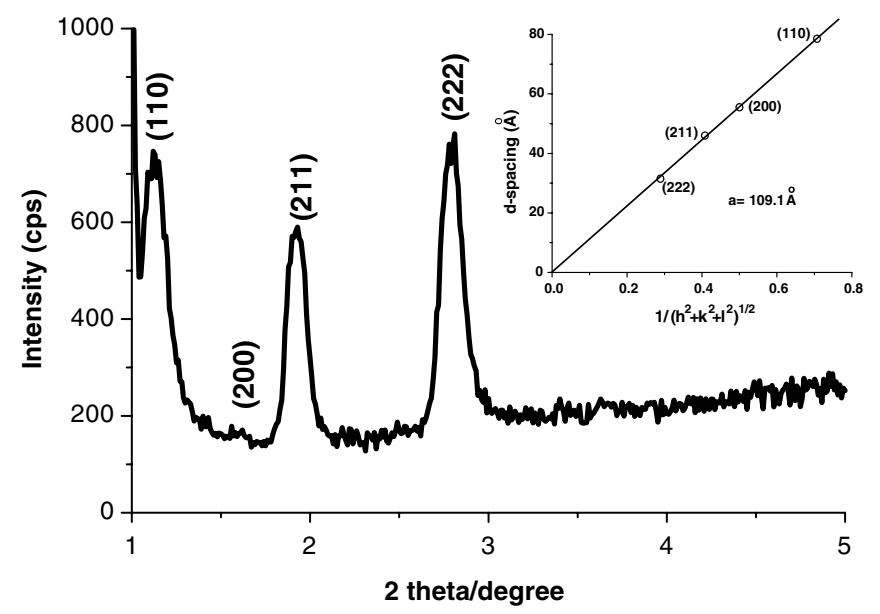

Fig. 7. The XRD pattern of a $\left[\mathrm{Zn}\left(\mathrm{H}_{2} \mathrm{O}\right)_{6}\right]\left(\mathrm{ClO}_{4}\right)_{2}-\mathrm{P} 123-\mathrm{mesoSiO}_{2}$ sample with 1 salt/P123 mole ratio. Inset is a plot of $d$-spacing versus the $(h k l)$ relation for a cubic structure. 
are required to further elucidate these structural transformations.

The $\left[\mathrm{Zn}\left(\mathrm{H}_{2} \mathrm{O}\right)_{6}\right]\left(\mathrm{NO}_{3}\right)_{2}-\mathrm{P} 123$-mesoSiO ${ }_{2}$ sample with a salt/P123 mole ratio of 1.0 was calcined at various temperatures up to $500{ }^{\circ} \mathrm{C}$. A typical TEM image of a calcined sample is shown in Fig. 8. It displays regular and well ordered mesopores with a lattice spacing consistent with the PXRD results. The temperature dependent calcinations lead to a phase change from lamella to hexagonal at around $300{ }^{\circ} \mathrm{C}$. Note also that the calcinations was carried in steps by heating the sample under laboratory atmosphere up to the temperatures $100,200,300$ and $500{ }^{\circ} \mathrm{C}$ and cooled to RT for recording the XRD patterns in each steps. Fig. 8 shows the PXRD patterns of the $\left[\mathrm{Zn}\left(\mathrm{H}_{2} \mathrm{O}\right)_{6}\right]\left(\mathrm{NO}_{3}\right)_{2}-\mathrm{P} 123-$ mesoSiO$_{2}$ sample with a salt/ P123 mole ratio of 1.0 before and after calcinations. The pattern before the calcinations has diffraction lines due to the (100), (200), (300) planes at $100.6 \AA, 50.3 \AA$ and $34.4 \AA$, respectively. However after calcinations at $300^{\circ} \mathrm{C}$ and $500{ }^{\circ} \mathrm{C}$ a new set of diffraction lines were observed at
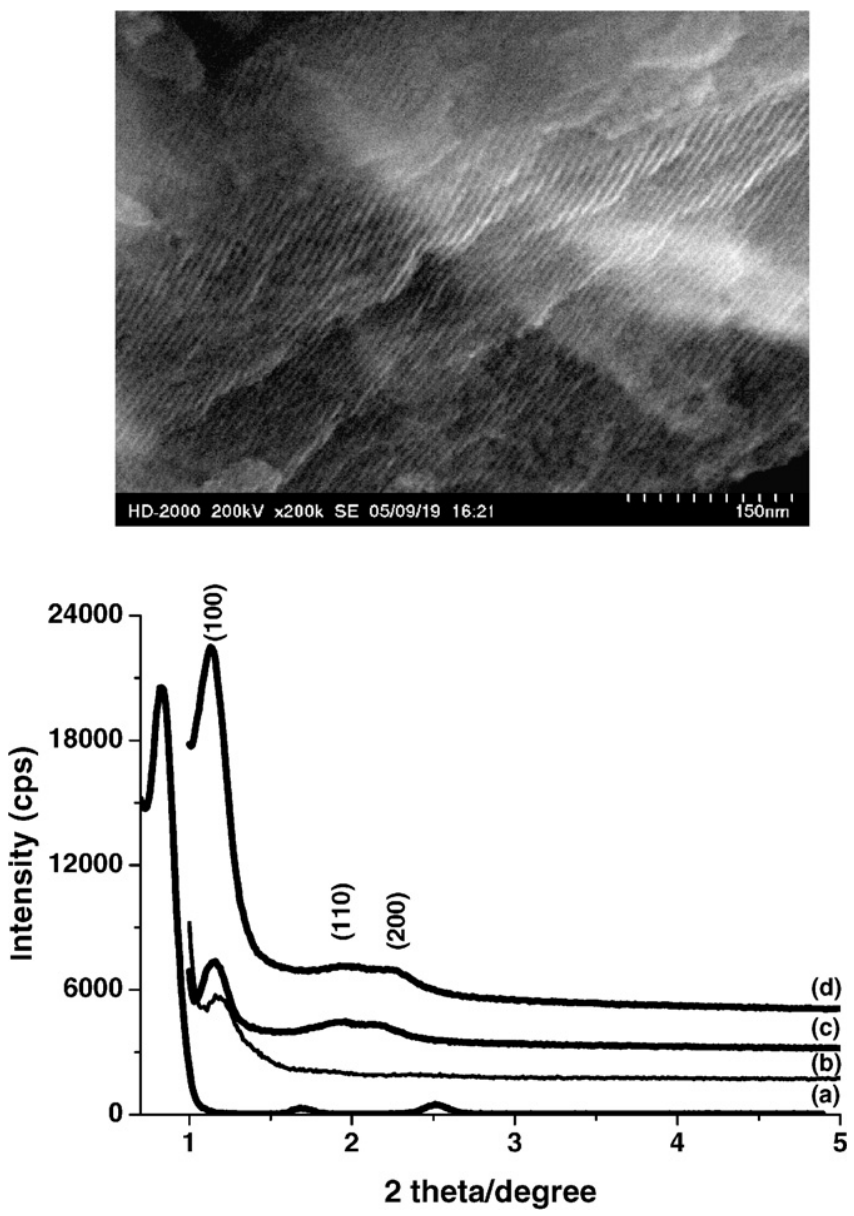

Fig. 8. (Top) A TEM image a piece of powder sample obtained after calcinations at $500{ }^{\circ} \mathrm{C}$ from the $\left[\mathrm{Zn}\left(\mathrm{H}_{2} \mathrm{O}\right)_{6}\right]\left(\mathrm{NO}_{3}\right)_{2}-\mathrm{P} 123-\mathrm{mesoSiO}_{2}$ sample with a salt/P123 mole ratio of 1 and (bottom) the XRD patterns of $\left[\mathrm{Zn}\left(\mathrm{H}_{2} \mathrm{O}\right)_{6}\right]\left(\mathrm{NO}_{3}\right)_{2}-\mathrm{P} 123-\mathrm{mesoSiO}_{2}$ with salt-to-P123 ratio 1 (a) before calcinations, (b) calcined at $200{ }^{\circ} \mathrm{C}$, (c) calcined at $300{ }^{\circ} \mathrm{C}$ and (d) calcined at $500^{\circ} \mathrm{C}$.
77.8, 46.1 and $39.4 \AA d$-spacing, indexed to the (100), (110) and (200) planes, respectively, of a 2D hexagonal structure. Note that the intensity of the (100) diffraction line increases as the temperature of the calcination increases, indicating some degree of ordering with the further condensation of silanol groups, $\mathrm{Si}-\mathrm{OH}$.

\section{Conclusion}

The LC mesophase of some TMS: $\mathrm{C}_{n} \mathrm{EO}_{m}$ and TMS:Pluronics systems have been used to produce mesostructured silica. The effects of $\left[\mathrm{Co}\left(\mathrm{H}_{2} \mathrm{O}\right)_{6}\right]\left(\mathrm{NO}_{3}\right)_{2}$, $\left[\mathrm{Zn}\left(\mathrm{H}_{2} \mathrm{O}\right)_{6}\right]\left(\mathrm{NO}_{3}\right)_{2},\left[\mathrm{Co}\left(\mathrm{H}_{2} \mathrm{O}\right)_{6}\right]\left(\mathrm{ClO}_{4}\right)_{2}$ and $\left[\mathrm{Zn}\left(\mathrm{H}_{2} \mathrm{O}\right)_{6}\right]-$ $\left(\mathrm{ClO}_{4}\right)_{2}$ salts to the LC mesophases and mesostructured silica were extensively studied. The $\left[\mathrm{Co}\left(\mathrm{H}_{2} \mathrm{O}\right)_{6}\right]\left(\mathrm{NO}_{3}\right)_{2}$ $\mathrm{C}_{12} \mathrm{EO}_{10}$-mesoSiO $\mathrm{m}_{2}$ materials have a hexagonal structure under a $1.2\left[\mathrm{Co}\left(\mathrm{H}_{2} \mathrm{O}\right)_{6}\right]\left(\mathrm{NO}_{3}\right)_{2} / \mathrm{C}_{12} \mathrm{EO}_{10}$ mole ratio whereas the structure is cubic above a $1.2 \mathrm{~mol}$ ratio. The $\left[\mathrm{Co}\left(\mathrm{H}_{2} \mathrm{O}\right)_{6}\right]\left(\mathrm{ClO}_{4}\right)_{2}-\mathrm{C}_{12} \mathrm{EO}_{10}-\mathrm{mesoSiO}_{2}$ materials have cubic mesostructures at much lower salt concentrations (0.2 mol ratio) than $\left[\mathrm{Co}\left(\mathrm{H}_{2} \mathrm{O}\right)_{6}\right]\left(\mathrm{NO}_{3}\right)_{2}-\mathrm{C}_{12} \mathrm{EO}_{10}$-mesoSiO materials. The coordination of the nitrate ion to the metal ion that reduces the ion density of the salt-surfactant-mes$\mathrm{oSiO}_{2}$ systems, plays an important role during the synthesis. There is an equilibrium between the hydrophilic and the hydrophobic content of the media. For example, the structure of the $\left[\mathrm{Co}\left(\mathrm{H}_{2} \mathrm{O}\right)_{6}\right]\left(\mathrm{NO}_{3}\right)_{2}-\mathrm{C}_{18} \mathrm{EO}_{10}$-mesoSiO materials are hexagonal up to a TMS $/ \mathrm{C}_{18} \mathrm{EO}_{10}$ mole ratio of 2.0 which is much higher than in the case of $\mathrm{C}_{12} \mathrm{EO}_{10}$ (1.2). An increase in the hydrophilic content shifts the equilibrium in favor of the cubic structure, whereas an increase in the hydrophobic content shifts the equilibrium towards the hexagonal structure.

The LC mesophases of TMS:Pluronic can also be used as a reaction media to produce mesostructured materials with different structures with larger pores. The $\left[\mathrm{M}\left(\mathrm{H}_{2} \mathrm{O}\right)_{6}\right]\left(\mathrm{NO}_{3}\right)_{2}-\mathrm{P} 123-\mathrm{mesoSiO}_{2}$ is lamella that transforms to $2 \mathrm{D}$ hexagonal mesoporous silica with calcinations under ambient conditions at around $300^{\circ} \mathrm{C}$. However, the $\left[\mathrm{M}\left(\mathrm{H}_{2} \mathrm{O}\right)_{6}\right]\left(\mathrm{ClO}_{4}\right)_{2}-\mathrm{P} 123-\mathrm{mesoSiO}_{2}$ is cubic.

\section{Acknowledgements}

The authors thank O. Samarskaya for her help with some experiments and helpful discussion and Dr. N. Coombs and Dr. M. Mamak for TEM imaging. For the financial support, ÖD gratefully acknowledges the Scientific and Technical Research Council of Turkey (TÜBITAK) in the framework of the project TBAG-2263 (102T188), the Turkish Academy of Science in the framework of Young Scientist Award (ÖD/TÜBA-GEBIP/2002-1-6) and Bilkent University (CHEM-01-05).

\section{References}

[1] C. Kresge, M. Leonowicz, W. Roth, C. Vartuli, J. Beck, Nature 359 (1992) 710. 
[2] T. Yanagisawa, T. Shimizu, K. Kuroda, C. Kato, Bull. Chem. Soc. Jpn. 63 (1990) 988.

[3] P.D. Yang, D.Y. Zhao, D.I. Margolese, B.F. Chmelka, G.D. Stucky, Nature 396 (1998) 152.

[4] T. Asefa, M.J. MacLachan, N. Coombs, G.A. Ozin, Nature 402 (1999) 867.

[5] Ö. Dag, O. Samarskaya, N. Coombs, G.A. Ozin, J. Mater. Chem. 13 (2003) 328

[6] P. Behrens, Adv. Mater. 5 (1993) 127.

[7] J.S. Beck, J.C. Vartulli, W.J. Roth, M.E. Leonowicz, C.T. Kresge, K.D. Schmitt, D.H. Olson, F.W. Sheppard, S.B. McCullen, J.B. Higgins, J.L. Schlenker, J. Am. Chem. Soc. 114 (1992) 10834.

[8] Q. Huo, D. Margolese, U. Siesla, P. Feng, T.E. Gler, P. Sieger, R. Leon, P. Petroff, F. Schuth, G. Stucky, Nature 368 (1994) 317.

[9] G.S. Attard, J.C. Glude, C.G. Goltner, Nature 378 (1995) 366

[10] D. Zhao, J. Feng, Q. Huo, B.F. Chmelka, G.D. Stucky, J. Am. Chem. Soc. 120 (1998) 6024.

[11] C.G. Göltner, S. Henke, M.C. Weissenberger, M. Antonietti, Angew. Chem. Int. Ed. 37 (1998) 613.

[12] S.A. Bagshaw, E. Prouzet, T.J. Pinnavaia, Science 269 (1995) 1242.

[13] Ö. Dag, I. Soten, Ö. Çelik, S. Polarz, N. Coombs, G.A. Ozin, Adv. Funct. Mater. 13 (2003) 30.

[14] S.Y. Choi, M. Mamak, N. Coombs, N. Chopra, G.A. Ozin, Adv. Funct. Mater. 14 (2004) 335.

[15] Ö. Çelik, Ö. Dag, Angew. Chem., Int. Ed. 40 (2001) 3800.

[16] Ö. Dag, S. Alayoğlu, I. Uysal, J. Phys. Chem. B 108 (2004) 8439.

[17] E. Leontidis, Curr. Opin. Colloid Interface Sci. 7 (2002) 81.

[18] G.S. Attard, S. Fuller, G.J.T. Tiddy, J. Phys. Chem. B 104 (2000) 10426 .
[19] H. Schott, J. Colloid Interface Sci. 189 (1997) 117.

[20] L. Zhang, P. Somasundaran, C. Maltesh, Langmuir 12 (1996) 2371.

[21] L.D. Charlton, A.P. Doherty, J. Phys. Chem. B 104 (2000) 8327.

[22] C. Washington, Langmuir 13 (1997) 4545.

[23] F. Hofmeister, Arch. Exp. Pathol. Pharmakol. 24 (1888) 247.

[24] M. Kahlweit, E. Lessner, R. Strey, J. Phys. Chem. 88 (1984) 1937.

[25] R. Ryoo, S. Jun, J. Phys. Chem. B 101 (1997) 317.

[26] C. Yu, B. Tian, J. Fan, G.D. Stucky, D. Zhao, J. Am. Chem. Soc. 124 (2002) 4556

[27] A.F. Demirörs, B.E. Eser, Ö. Dag, Langmuir 21 (2005) 4156.

[28] Ö. Dag, S. Alayoğlu, C. Tura, Ö. Çelik, Chem. Mater. 15 (2003) 2711.

[29] Ö. Dag, O. Samarskaya, C. Tura, A. Gunay, Ö. Çelik, Langmuir 19 (2003) 3671.

[30] G. Oyea, J. Sjoblom, M. Stocke, Adv. Colloid Interface Sci. 89-90 (2001) 439.

[31] P. Sakya, J.M. Seddon, R.H. Templer, R.J. Mirkin, G.J.T. Tiddy, Langmuir 13 (1997) 3706

[32] P. Alexandridis, D. Zhou, A. Khan, Langmuir 12 (1996) 2690.

[33] P. Alexandridis, U. Olsson, B. Lindman, Langmuir 14 (1998) 2627.

[34] D.Y. Zhao, J.L. Feng, Q.S. Huo, N. Melosh, G.H. Fredrickson, B.F. Chmelka, G.D. Stucky, Science 279 (1998) 548.

[35] F. Kleitz, W. Schmidt, F. Schuth, Micropor. Mesopor. Mater. 65 (2003) 1.

[36] H.F. Yang, Q.Y. Lu, F. Gao, Q.H. Shi, Y. Yan, F.Q. Zhang, S.H. Xie, B. Tu, D.Y. Zhao, Adv. Funct. Mater. 15 (2005) 1377.

[37] Y. Meng, Z.Y. Wu, Y.L. Wei, J.H. Zhu, Micropor. Mesopor. Mater. $84(2005) 127$. 